Paper title:

\title{
In search of heterotopia? Visitor motivations to an English
}

\section{Cathedral}

Pre-refereeing version of a paper published in 2010 on:

INTERNATIONAL JOURNAL OF TOURISM RESEARCH

Int. J. Tourism Res. 12, 750-760 (2010)

Published online 1 June 2010 in Wiley Online Library

(wileyonlinelibrary.com) DOI: 10.1002/jtr.790

Paper authors:

Gutic, Jorge; Caie, Eliza and Clegg, Andrew.

University of Chichester, Tourism Management Department

Correspondence address:

University of Chichester, Tourism Management Department, Bognor Regis Campus, Upper Bognor Road, Bognor Regis, PO21 1HR

Electronic correspondence address:

All electronic communications should be addressed to Dr. Jorge Gutic at: j.gutic@chi.ac.uk

\section{ABSTRACT}

According to Shackley (2002, after Foucault, 1986), the motivation of most visitors to cathedral is the search for heterotopia, which is defined as a sense of timelessness and spirituality. Shackley goes on to argue that this search for heterotopia is a conscious, even if sometimes not articulated, attempt by visitors to connect to an unchanging and transcendental space that provides spiritual meaning in a life of transient and ephemeral values. Shackley (2002:350) proposes that visitors to cathedrals recognise them as sacred space and are influenced by them, even if they cannot articulate or recognise that effect. 
This paper explores the idea that many visitors to sacred sites and cathedrals in particular, are motivated to do so by a search of spirituality, but that this search is acting as a subconscious, unspoken motivation, which may be hidden by more rational motivations such as curiosity, a desire to learn, or an interest in history and architecture. This paper argues that although more than a third of visitors to Chichester Cathedral are motivated by a search for spirituality or heterotopia as described by Shackley (2002), their motivation is often not the result of a conscious decision, but instead appears to be the result of a subconscious motivation. This finding also suggests that a significant proportion of the tourists that, according to Sharpley and Sundaran (2005), would claim to be motivated by curiosity or a desire to learn when visiting sacred or pilgrimage sites (the 'Tourist trail followers' and the (Practitioners'), may actually be subconsciously seeking some sense of spiritual experience or fulfilment. This proposition is based on a comparison between what visitors to Chichester Cathedral articulated as their primary motivation to visit the site, and those aspects that they found more satisfying from their visit, as well as the adjectives used to describe the Cathedral after their visit. This theory of subconscious motivation is developed from research on place meaning by Young (1999) and on consumer narratives of cathedral visitors by Voase (2007), and suggests that place meanings and personal narratives for cathedrals are socially constructed and attributed to the place according to the visitor's motivations. In this case, place meaning is acting as a mechanism to create intrinsic benefits that satisfy the visitor's motivational needs, with this process operating at an individual, subconscious level (Young, 1999; Pearce and Caltabiano, 1983). 
Thus, this paper concludes that a significant proportion of the non-religious visitors to cathedrals who argue that their motivations do not include the expectation of finding a sense of spirituality are justifying the benefits derived from visiting these sites by creating place meanings that have a spiritual dimension attached to it. This spiritual dimension arises from the subconscious acceptance of, and the associated behaviour connected to, the sanctity of space that visitors attach to the place.

Keywords: cathedral, heterotopia, visitor motivations, subconscious motivations

\section{INTRODUCTION}

\subsection{Cathedrals as Tourism Attractions}

The twenty-first century traveller is a product of an increasingly secular society and whilst sacred sites are still popular tourist destinations, traveller's motivations have become increasingly varied. Yunis (2006) identifies two distinctly different types of present-day religious tourism: pilgrimages and visits to sacred places for devotion, spirituality and worship; and tourism that takes place in religious buildings or sites, which can be regarded as a type of cultural tourism with historical, architectural and artistic components, which may include a spiritual dimension.

A 2007 survey (Project ASPIRE, 2007) confirmed that $85 \%$ of the British population had visited a church building or place of worship in the previous 12 months, for reasons ranging from participating in worship to attending concerts, community events or simply wanting a quiet space. On average $75 \%$ of those with no religious affiliation said that they had been in a church or place of worship during the same 
period. Overall 12.5 million people visit Church of England cathedrals, including 300,000 pupils on school visits (Project ASPIRE, 2007).

In Britain, a total of seventy cathedrals attract numerous visitors, particularly the five which are designated World Heritage sites: Bath, Durham and Canterbury Cathedrals, Fountains Abbey and Westminster Abbey. Shackley (2002) suggest that English cathedrals receive 30 million visits annually, and according to a report commissioned by the Association of English Cathedrals and English Heritage (Sacred Britain, 2006), visitors to English cathedrals generated £91 million in spending and directly supported 2,800 jobs in 2004 .

There is no doubt that Britain's cathedrals have become influential members of the visitor attractions' market, however, they find themselves in a unique position. Places of worship are, by definition, primarily concerned with "conservation and preservation of both site and religious tradition, as opposed to provision of facilities for visitors" (Shackley, 2001:19). The Christian tradition upholds the sanctity of the church building and the primary function of the cathedral as a "centre of worship and mission" (Chichester Cathedral, 2007a). Therefore, although cathedrals may share with other visitor attractions the desire to encourage and welcome visitors, the primary motivation is philanthropic, not financial profit. Many faith communities have recognised that, whatever the views of church members concerning tourism, there is a clear need to manage visitors in a manner which is sustainable, protects the fabric of the site and is sympathetic to the needs of pilgrims and visitors (Shackley, 2001).

The 2006 International Conference on Religious Tourism (ICORET, 2006) proposed that the development of religious tourism should: 1) protect the physical 
integrity of the religious sites and respect its religious significance, 2) ensure the wellbeing of the host community and preserve its priority right to use the religious places to ensure the visitor's fulfilment, and 3) reconcile the commercial needs of the tourism industry with the spiritual and religious needs of pilgrimages and worshippers. However, few churches are equipped with the expertise or finances to market themselves effectively to tourists or manage their impacts (Sacred Sussex, 2007). Regardless of expertise and financial shortcomings, it is clear that British churches and cathedrals will have to manage an increasing number of visitors in a way that maximises their benefits while keeping to a minimum the disruption to the church community and damage to the fabric of their buildings.

\subsection{Visitor Management at Britain's Cathedral Sites}

Visitor management strategies are becoming a focus of attention at cathedrals due to increasing visitor numbers and their diverse motivations. Conflict may arise if the behaviour of one group of visitors detracts from the experience of another (Shackley, 2001), making management essential to protect the well-being of all users. Visitors who wish to reminisce, take photographs and discuss the art and architecture in a cathedral, will inevitably clash with those seeking quiet contemplation and who wish to remain undisturbed. Visitors may have very little understanding of the etiquette expected in a sacred environment, potentially resulting in behaviour which offends the worshipping community (Chitty and Baker, 1999).

Shackley (2001:35) suggests that improper behaviour can be a result of "extensive cultural distance between the function and the purpose of the site and the background of the visitors". This lack of understanding provides challenges for site managers as they seek to protect the overall ambience, which is the essential core 
experience of a visit to a sacred site (Uzzell, 1989). In order to overcome these challenges, Blackwell (2007:46) argues that managers should understand and classify visitors' motivations and use them to inform their management strategies, so that sacred sites are managed to meet the needs of their various visitors to the extend possible.

\subsection{Visitor Motivations to Cathedral Sites}

Shackley (2001:94) suggests that, in management terms, sacred sites break all the rules for success as visitor attractions, arguing that they can be "exceptionally successful at attracting large numbers of visitors even if they have no discernable management to speak of, make use of no modern interpretation techniques, have minimal visitor facilities and are extremely difficult to reach". She attributes this success to the fact that visitor motivations are quite distinct from those of typical heritage tourists.

The Churches Tourism Association's Agenda for Action (Sacred Britain, 2006) suggest that among the reasons that make churches attractive to visitors other than worship include architecture, art, decorative interest, tranquility, "sacred space" and personal contact with the "soul" of a place. In terms of who visits churches, the market is defined into a range of segments including "church crawlers" who are the committed core market; educational visitors, both formal and informal; special interest groups such as those engaged in family history research; short-break explorers, and haven seekers, understood as those looking for a quiet place (Sacred Britain, 2006).

Although the limited UK research on the topic by the Churches Tourism Association (Sacred Britain, 2006) has identified a wide range of motives to visit 
sacred sites, according to Shackley (2002, after Foucault, 1986), the main motivation for most visitors to cathedral attractions can be construed as a search for a sense of timelessness and spirituality, which Shackley defines as heterotopia. Shackley goes on to argue that this search for heterotopia is a conscious, even if sometimes not articulate, attempt by visitors to connect to an unchanging and transcendental space that that provides spiritual meaning in a life of transient and ephemeral values.

This paper sets out to identify the motivations of tourists visiting a English Cathedral (Chichester City Cathedral), and it shows that although more than a third of visitors appear to be motivated by a search for spirituality or heterotopia, this motivation is often not the result of a conscious decision but instead appears to be the result of a subconscious process for these visitors. This finding also suggest that a significant proportion of the tourists that, according to Sharpley and Sundaran (2005), claim to be motivated by curiosity or a desire to learn when visiting sacred or pilgrimage sites (the 'Tourist trail followers' and the 'Practitioners'), may actually be subconsciously seeking some sense of spiritual experience or fulfilment. This conclusion is reached on the basis of a comparison between what visitors to Chichester Cathedral articulated as their primary motivation to visit this site, and those aspects that they found more satisfying from their visit, as well as the adjectives used to describe the Cathedral after their visit. This theory of subconscious motivation is based and developed from research on place meaning by Young (1999) and on consumer narratives of cathedral visitors by Voase (2007), by arguing that place meanings and personal narratives for cathedrals are socially constructed and attributed to the place according to the visitor's motivations. In this case, place meaning is acting as a mechanism to create intrinsic benefits that satisfy the visitor's motivational needs, with this process operating at an individual, subconscious level 
(Young, 1999; Pearce and Caltabiano, 1983). The need to create these intrinsic benefits arises from the preconceived narratives that cathedral visitors deploy in order to generate meaning out of their visitor experience. This paper concludes by suggesting that the inability by some visitors to understand or recognise their main motivation driver to visit cathedral sites makes difficult for their managers to appropriately manage tourism impacts. Implications for cathedral management are also highlighted as part of the conclusion.

\section{THE LOCAL CONTEXT: CHICHESTER CATHEDRAL}

Chichester city sits in the heart of Chichester District, situated on the south coast of England in the county of Sussex. Chichester Cathedral is situated in the centre of the city on the fringe of the pedestrian shopping area and is a Norman construction, consecrated in 1108. Chichester Cathedral contains the shrine of St Peter, Bishop of Chichester (canonised in 1262), which is a focus of pilgrimage; the 'Arundel Tomb' (inspiration for a Philip Larkin poem); and the burial site of composer Gustav Holst. Several prominent works of art have been commissioned by the cathedral in recent years from artists of world renown. These include paintings by Lambert Barnard, Hans Feibusch and Graham Sutherland; tapestries by John Piper and Ursula Benker-Schirmer; stained glass by Mark Chagall; and a sculpture by Philip Jackson (Chichester Cathedral 2007b).

Chichester Cathedral is open daily with no admission charge. Visitors are welcomed at the door by members of a large team of volunteer stewards. Complimentary information leaflets are distributed in a number of languages and a children's guide is provided. A glossy, souvenir guidebook is available for purchase at 
$£ 5.00$. There is a small exhibition of items from the cathedral treasury in a side-chapel with a nominal entrance fee of 50 pence. Free guided tours take place twice daily and roving guides are accessible at other times to answer questions. A visitor information and display area was introduced into the cathedral in 2006, providing a staffed information desk for enquiries and updates on the restoration project. The cathedral cloisters were redeveloped in 2006 to accommodate new restaurant and toilet facilities and a relocated gift shop (Chichester Cathedral 2007b).

Visitor numbers to the cathedral were not accurately quantified until an electronic counter was installed at the main entrance door in 2006 , when 333,000 people accessing the building were recorded. It is estimated that 191,000 of these were visitors, although this figure is imprecise due to the difficulty of distinguishing 'casual visitors' from other users. In addition, during 2006 6,394 people visited as prebooked groups, 3,344 of whom had a guided tour (Chichester Cathedral 2007a).

\section{METHODOLOGY}

A self-administered questionnaire was used to collect the data for this study (Appendix One). The data concerning this paper was obtained from eight questions related to visitor's attitudes and perceptions regarding their visit; their aim being to ascertain visitor motivations and levels of customer satisfaction. The section began with open questions about the most and least satisfying aspects of the visit. A fivepoint Likert scale was then provided for scoring the importance of, and satisfaction with, various aspects of the visit. The survey concluded with an open question inviting respondents to describe the cathedral in three words. 
Fieldwork was carried out over an eleven-day period between $17^{\text {th }}$ and $27^{\text {th }}$ August 2007. The data collection period covered two weekends, one of which was a Bank Holiday weekend, and three days midweek; with the peak holiday period purposefully chosen to maximise the number of casual visitors and to allow comparison of visitor profiles and attitudes across a variety of scenarios. There were no special events taking place at the cathedral during this time. Data collection was carried out at regular times between 10am and 6pm to ensure a good cross-section of visitors. Care was taken to avoid times of formal worship to increase the chance that respondents would be casual visitors.

A sample size of 350 respondents was chosen for this research. Respondents were selected at random and the total number of valid questionnaires returned was 352 , with a response rate in the region of $85 \%$. The completed questionnaires were processed using Microsoft Office Excel (Microsoft, 2003), with further analysis obtained using data comparison functions on Microsoft Office Access (Microsoft, 2003).

Although the relatively small sample size means that it is not possible to extrapolate the results to the overall population of visitors to Chichester cathedral or any other cathedrals in the UK, it is sufficient to provide a useful indication of the breadth of opinion and attitudes under investigation.

\section{RESULTS}

\subsection{Respondents stated motivations for their visit}


A key objective of this study was to identify respondents' motivations to visit Chichester cathedral. Visitors where asked to state their primary reason for visiting the cathedral and the reasons given by $72 \%$ of respondents suggest that they perceive Chichester Cathedral's primary function as a visitor attraction, rather than a place to visit for religious activities. This included $26 \%$ of respondents who had an interest in the history of the building as their main motivation; closely followed by an interest in the architecture (23\%), curiosity (19\%), and $4 \%$ of respondents that visited the cathedral as part of an organised visitor group. Only $14 \%$ of respondents gave spiritual reasons for their visit, with $7 \%$ mentioning activities associated with the Christian tradition of the church as their main motivation (prayer, reflection, worship and pilgrimage), and a further $7 \%$ indicated a desire for peace and solitude as the main reason for their visit (Figure 4.1).

Figure 4.1 Main Reason for Visiting the Cathedral (Percentage of Visitors)

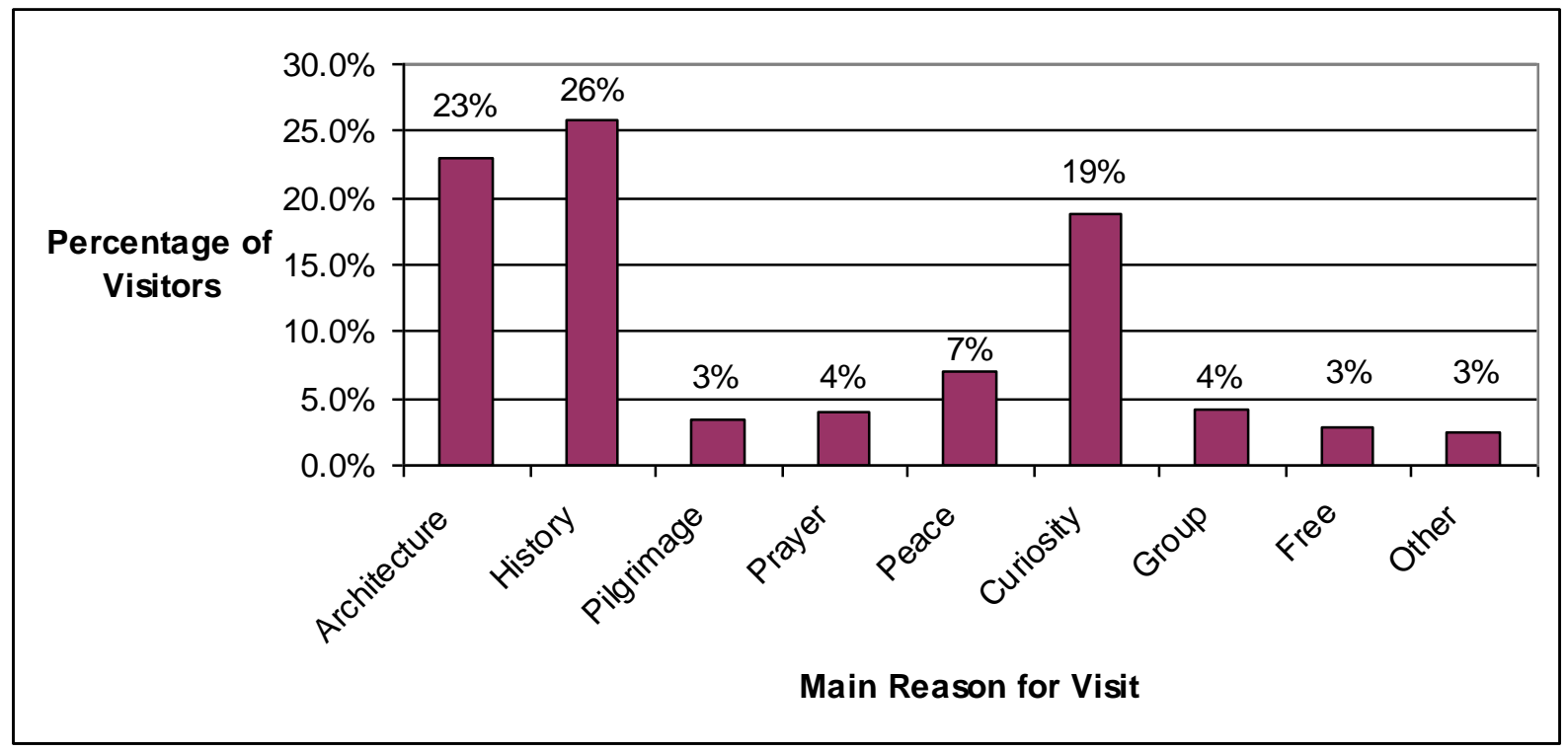

Two out of the three most cited motives stated by respondents (architecture and history) are consistent with one of the primary motives for visitors to sacred places 
identified by the Churches Tourism Association: an architectural and heritage interest in the building (Churches Tourism Association, 2007a; 2007b). These results also appear to suggest that only a minority of 49 visitors (14\%, the aggregation of those who claimed pilgrimage, prayer and peace motives) are there in search of a spiritual experience.

\subsection{Respondents most and least satisfying aspects of the visit}

The main motivations stated by respondents to visit Chichester Cathedral would appear to confirm the view of Sharpley and Sundaram (2005) that tourists visiting sacred sites often have little expectation of a spiritual encounter. However, in response to an open-ended question which asked respondents to identify which aspect of their visit had been particularly satisfying, a significantly larger proportion of visitors (35\%) gave answers which would indicate some degree of emotional or spiritual experience (Table 4.1 and Appendix 2). Those aspects mentioned by these 123 respondents which fall within this spiritual or emotional category included peace, quiet, solitude (64\%); staff warmness and welcome at door (30\%); the Cathedral's atmosphere or ambience (29\%); the opportunity to pray, reflect, pay respects, light candles (20\%); Christian witness of Cathedral (10\%) and prayers read on each hour $(4 \%)$.

Table 4.1 Summary of Responses to 'Most Satisfying Aspect of Visit'

\section{Question}

\begin{tabular}{|l|c|}
\hline Aspects Relating to Architecture & $\begin{array}{c}47 \% \\
\text { (167 responses) }\end{array}$ \\
\hline Aspects Relating to Spiritual/Emotional Experience & $\begin{array}{c}35 \% \\
\text { (123 responses) }\end{array}$ \\
\hline Aspects Relating to History of Building & $\begin{array}{c}8 \% \\
\text { (31 responses) }\end{array}$ \\
\hline
\end{tabular}


There also appear to exist a dissonance between those visitors that claimed history was their main visit motivation (26\%, the single highest motivation) and those who found this aspect the most satisfying $(8 \%)$. It is unlikely that this could be attributed to the expectations of these visitors not being met, as respondents were asked to give details of any aspect of their visit which had disappointed them. Only eight negative comments were received concerning the history of the building and all these related directly to a lack of interpretative information about particular aspects of the building, including a lack of translations of Latin inscriptions or lack of information about the stained glass windows (Table 4.2 and Appendix 3 ). It is also unlikely that this result could be attributed to the visitor experience not being satisfactory, as only a total of thirty-one comments were received concerning aspects of the visit which disappointed respondents. This figure equates to less than $9 \%$ of the total survey group and indicates that the general level of satisfaction with the visitor experience was very high. This result appears to suggest that visitors were not disappointed by the history of the building but, on reflection, they did not consider the building's history such a significant part of their visit.

Table 4.2 Summary of Responses to 'Disappointing Aspect of Visit' Question

\begin{tabular}{|l|c|}
\hline Aspects directly relating to Visitor Management & $\begin{array}{c}48 \% \\
\text { (15 responses) }\end{array}$ \\
\hline Aspects directly relating to Lack of Information about History & $26 \%$ \\
& (8 responses) \\
\hline Aspects directly relating to Architecture/Building & $19 \%$ \\
& (6 responses) \\
\hline
\end{tabular}




\subsection{Relative Importance of Aspects of the Visit}

Visitors were asked to rank on a 5-point Likert scale eleven aspects of their visit in order of importance in relation to their motivations to visit the Cathedral. These eleven aspects can be broadly grouped on five categories of motivations: architecture, history, spiritual aspects, cathedral use and access, and visitor facilities. The architecture was identified by respondents as the most important aspect of the visit, receiving the highest ranking score (1) from $61 \%$ of respondents. The historical interest of the building was a close second, ranked highest by $56 \%$ of respondents, with spiritual aspects (peace and quiet areas) and facilities relating to the cathedral's use and access (access, information, free attraction) both ranked in a third, equally important group of motivations for about $25 \%$ of respondents in each of them (Figure 4.2). Those aspects relating to the cathedral's visitor facilities (shop, café, exhibition and guided tours) were ranked very low by most visitors, with only about $8 \%$ of respondents mentioning as important aspect of their visit. 
Figure 4.2 Relative Importance of Aspects of Visit (Total Number of Visitors)

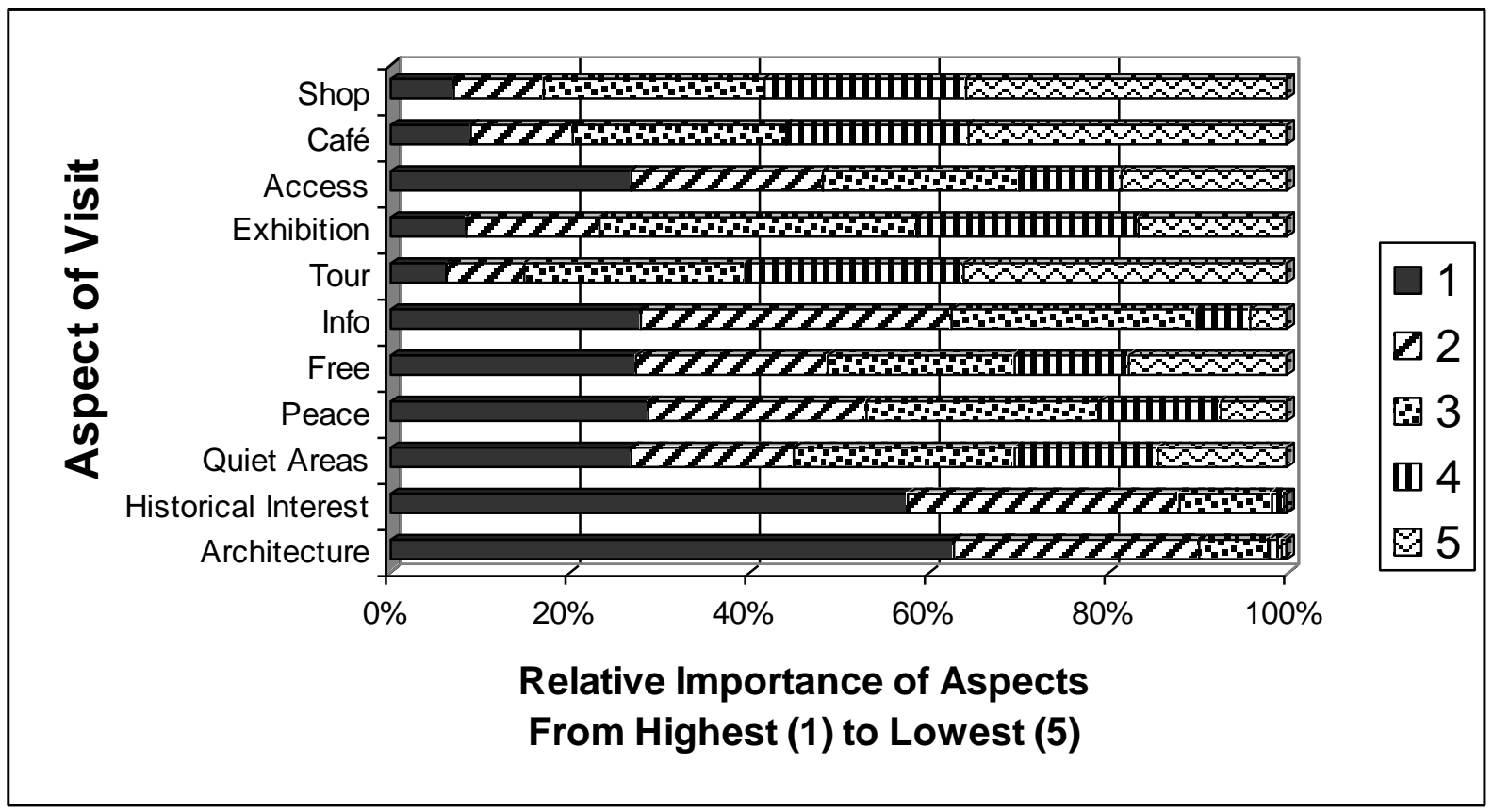

These results again show a significant dissonance between what visitors think are important motivations for them to visit the cathedral, and those aspects that are actually providing satisfaction in terms of their visit (Table 4.1), with both architecture and history apparently being overrated as important by respondents when questioned about their motives, while emotional and spiritual motives were underrated as potentially important motivations. These findings also support the theory proposed by Shackley (2001) that sacred sites are distinct from other heritage attractions, in that they can operate successfully with fewer visitor facilities, as these don't seem to be rated as significant in terms of visitor motivation or satisfaction.

\subsection{Adjectives used by respondents to describe the cathedral}


Respondents were asked to describe the cathedral in three words. 861 adjectives were provided (Appendix 4). Twelve themes emerged (Table 4.3), the most common theme referred to the peace and ambience of the building (188), followed by the beauty and architecture (184), size (98), educational (87) and history (77). Words describing the cathedral as part of a spiritual/emotional experience (72) ranked sixth in the themes presented by respondents' comments, followed by welcoming atmosphere (61).

Table 4.3 Summary of Adjectives Used to Describe Cathedral (Themes)

\begin{tabular}{|l|c|}
\hline \multicolumn{1}{|l|}{ Theme of Adjectives Used } & $\begin{array}{c}\text { Total Number of } \\
\text { Responses }\end{array}$ \\
\hline 1. Peacefulness of Building & 188 \\
\hline 2. Beauty and Architecture & 184 \\
\hline 3. Size & 98 \\
\hline 4. Educational Aspects & 87 \\
\hline 5. History & 77 \\
\hline 6. Spiritual/Emotional Experience & 72 \\
\hline 7. Welcoming Atmosphere & 61 \\
\hline 8. Simplicity & 34 \\
\hline 9. Religious Function & 29 \\
\hline 10. Good Maintenance & 28 \\
\hline 11. Negative Comments & 16 \\
\hline 12. Access & 4 \\
\hline
\end{tabular}

By aggregating the frequency of words describing the peaceful, spiritual, emotional, welcoming atmosphere and religious character of the building (themes 1, 6 , 7 and $9 ; 41 \%$ of the comments), it is possible to suggest that a significant number of respondents experienced their visit as affecting them emotionally, and indicate that the 
emotional or spiritual experience may be stronger that respondents' initial motivations appear to suggest. These results partly reflect the pattern for the most satisfying aspect of the visit (Table 4.1), but they also suggest that spiritual aspects may be more important for visitors that their motivations and satisfying aspects of the visit appear to suggest, and also highlight the significance of a new element (educational value of the building) that did not appears among the respondents' initial motivations (Table 4.4).

Table 4.4 Percentage of Adjectives Used to Describe Cathedral, by Aggregated Themes.

\begin{tabular}{|l|c|}
\hline Aggregated Themes & $\begin{array}{c}\text { Percentage of } \\
\text { Responses }\end{array}$ \\
\hline $\begin{array}{l}\text { Emotional / spiritual (Themes 1, 6, } \\
7 \text { and 9) }\end{array}$ & $41 \%$ \\
\hline Architecture (Themes 2 and 3) & $32 \%$ \\
\hline Educational (Theme 4) & $10 \%$ \\
\hline History (Theme 5) & $9 \%$ \\
\hline
\end{tabular}

\section{DISCUSSION}

The aim of this paper was to identify the motivations of tourists visiting Chichester Cathedral and when directly questioned about their motives to visit the Cathedral, only a minority (14\%) of the respondents appeared to be motivated by spiritual or emotional reasons, whereas an interest in history or architecture were cited as the most common motivations by the majority of visitors $(26 \%$ and $23 \%$ respectively). However, when assessing visitor motives from the point of view of satisfaction or description of the experience, $35 \%$ to $41 \%$ of respondents gave 
answers that indicate a sense of spirituality or emotional involvement as part of their motivations to visit the Cathedral. Thus, it would appear that although spiritual or emotional elements are important motivators for a significant number of visitors to Chichester Cathedral (Shackley's (2002) search for heterotopia), these motivators appear not to be the result of a conscious choice, but instead the result of a subconscious process.

This begs the question of why if spiritual or emotional reasons are important motivations, they are not recognised as such by some of the visitors to Chichester Cathedral. In order to understand this behaviour it is useful to discuss how visitors to sacred sites tend to perceive the spaces they are visiting. According to Jackson and Henrie (1983), sacred space is never perceived nor used in an abstract void of values, as they always have a specific mystico-religious value attached to them by the cultural groups that regard the site as sacred. Even if the visitors to these sites regard themselves as non-religious or non-believers, almost unavoidably they will be aware of the sanctity that the site's original users attach to it (Jackson and Henrie, 1983: 95), and thus would be compelled to act and behave within certain parameters that, in the mind of these visitors, recognises and acknowledges the religious value attached to the visited space. Voase (2007:50) also argues that by entering a building that through its architecture and scale is conspicuously proclaiming a discourse-of-the-Divine, visitors are forced to examine their own religious narratives and personal beliefs. Further, even if non-believing visitors may not necessarily accept the sanctity of the space they are visiting, as part of the site's religious value they will be implicit or stated behaviour and dress codes that visitors would need to acknowledge if they want to gain access to the site. 
From this recognition of sanctity of space it follows that even if visitors don't necessary believe or share the cultural values that make a site sacred, and they may only visit the site out of curiosity or a desire to learn - Sharpley and Sundaran's (2005) 'Tourist trail followers' and 'Practitioners' -, their visitor experience and appreciation of the place will be modulated by their knowledge of other groups' views on the sanctity of the place; by how that religious discourse affects their own emotional and spiritual narratives (Voase, 2007); and by what they perceive it is acceptable or respectful behaviour, suitable to the characteristics of the site.

This potentially unconscious recognition of the sanctity of space, that may lead to a non-religious visitor to a cathedral to avoid boisterous behaviour and to speak in hushed voice and reverent tone, by necessity creates a perceptual interface between the site and the visitor's perception of it, that will mediate the visitor experience and it is likely to lead to a feeling of liminality (Graburn, 1989; cited in Sharpley and Sundaran, 2005:163).

Thus, even those visitors that are not intently looking for a feeling of spirituality as their prime motivation to visit a cathedral are likely to derive some sense of sanctity from their visit. This feeling of liminality may be fulfilling some of the complex selfactualisation needs that Pearce and Caltabiano (1983:18) argue often act as 'hidden' motivational factors for tourists, particularly for those at the experienced end of the travel spectrum, who by nature are more likely to be interested in cultural and learning experiences. This subconscious search for self-actualisation derived from visiting a sacred place such a cathedral also requires the visitor to formulate a selective place meaning attached to the destination that will create the psychological benefits that justify visiting it (Young, 1999). 
According to Young (1999: 401) place meanings are socially constructed and attributed to the place according to the visitor's motivations, with this place meaning acting as a mechanism to create intrinsic benefits that satisfy the visitor's motivational needs, in a process operating at an individual, subconscious level (Young, 1999; Pearce and Caltabiano, 1983: 16). Thus, it can be suggested that when questioned, non-religious visitors to cathedrals (Sharpley and Sundaran's (2005) 'Tourist trail followers' and 'Practitioners') are likely to claim that their motivations do not include the expectation of finding a sense of spirituality. However, the results of this research suggest that at least a third of visitors to Chichester Cathedral claiming such nonreligious motivations create place meanings with an emotional - spiritual dimension, and it is suggested that they are doing so in order to create satisfactory benefits that justify their visit to the cathedral.

According to Voase (2007:50), visitors arrive to cathedrals with a set of personal narratives in their heads, which shape their expectations in a process that is primarily affective rather than a cognitive one. These narratives partly concern the visitors' personal relationship with the discourse-of-the-Divine, which they expect to be augmented through the encounter with the cathedral. Further, Voase's research suggests that those visitors whose expectations remain unfulfilled after the visit are those who have sought or have been offered (through site interpretation) an intellectual rather than emotional experience.

Instead, it is suggested (Voase, 2007:51) that a cathedral visit is a romantic experience of primarily emotional nature, product of affective and reflective processes engendered around visitors' personal narratives, which are deployed in order to 
generate meaning out of their experience. This research proposes that these personal narratives further reinforce the place meanings that according to Young (1999) visitors formulate to create intrinsic benefits to their visit and, due to the mainly emotional nature of cathedral visitors' personal narratives, are likely to be acting over their motivations at a subconscious level.

Although this research did not attempted to identify why this subconscious spiritual dimension attached to motivations arises, it is proposed that its origin may lay in the subconscious acceptance of, and the associated behaviour connected to, the sanctity of space that non-religious visitors need to attach to the place in order to gain access to it (Jackson and Henrie, 1983), and which is likely to force visitors to examine their own religious narratives and preconceptions of the meaning of sacred cathedral space in order to generate benefits out of their visitor experience (Voase, 2007).

\section{CONCLUSION}

This study set out to identify the motivations of visitors to Chichester Cathedral, and on the basis of its results it argues that as much as a third of visitors to cathedrals may be doing so due to subconscious motivations relating to a sense of spirituality, which are created in order to justify the benefits derived from their visit. This has clear implications for cathedral managers, because the inability by some visitors to understand or recognise their main motivation to visit these sites will make difficult to appropriately manage their impacts.

Visitors who don't recognise their motivations to visit a cathedral may not respond well to management measures directed at increasing visitor satisfaction, such 
as interpretative information or guided tours, as these will not necessarily add value to someone looking to fulfil subconscious emotional - spiritual motivations. Further, these visitors may not respond to cathedral managers' marketing efforts directed at highlighting non-spiritual aspects of the attraction such as its history or architecture, and may develop a negative perception towards entry fees or any other effort aimed at raising income from visitors in order to support the management of the site.

An implication of this finding for cathedral visitor management in general and visitor interpretation in particular, is that managers must recognise the emotional spiritual motivations of its visitors. Due to the subconscious nature of these motivations, it is necessary to develop information and interpretative materials that address the human-emotional dimension of the visitor experience that would allow visitors to develop Voase's (2007:51) "sense of human connectedness".

Managers also need to recognise that visitors may be seeking this emotional dimension at a subconscious level and as such they may not want to openly acknowledge, to either themselves or to cathedral managers and researchers, that there is an emotional - spiritual dimension attached to their visit. Thus, it wouldn't be appropriate to produce interpretative material addressing visitors' feelings which, associated as part of the interpretation, would have overt or implied religious or faith messages, as visitors are likely to reject these.

\section{REFERENCES}


ASPIRE (2007) 'Audiences for Sacred Places in the Regions', Project Information, accessed on $22 / 11 / 07$

http://aspireproject.info/index.php?option=com content\&task=blogsection\&id=1\&ltemi $\underline{\mathrm{d}=26}$.

Blackwell, R. (2007) Motivations for religious tourism, pilgrimage, festivals and events, Ch. 3 in Raj, R. and Morphet, N. (Eds): Religious tourism and pilgrimage festivals management: an international perspective. CAB International, London.

Chichester Cathedral (2007a) Annual Report March 2007, accessed on 2/11/07 http://chichestercathedral.co.uk/dyn/ folder3/AnnualReportforwebsite.pdf.

Chichester Cathedral (2007b) Official Web-site, accessed on 13/2/07 http://www.chichestercathedral.org.uk/index-flash.html.

Chitty, G. and Baker, D. (1999) Managing Historic Sites and Buildings. Routledge, London.

Churches Tourism Association (2007a) Information on Sacred Britain Strategy, accessed on $1 / 11 / 07$

http://www.churchestourismassociation.info/index.php?option=com content\&task=blo gsection\&id=8\&Itemid=35.

Churches Tourism Association (2007b) Response to Government Tourism Enquiry, accessed on $21 / 11 / 07$ 
http://www.churchestourismassociation.info/index.php?option=com docman\&task=cat view\&gid=17\&ltemid $=41$.

Foucault, M. (1986) Other spaces: the principles of heterotopia. Lotus International, 48-49: 9-17.

ICORET (2006) International Conference on Religious Tourism, Conclusion and Recommendations, accessed on 6/11/07

http://icoret.metacanvas.com/EN/conference/conclusionsrecommendationsdraft.html.

Jackson, R. and Henrie, R. (1983) Perceptions of sacred space. Journal of Cultural Geography, 3: 94-107.

Microsoft (2003) Microsoft Office Professional Edition, Microsoft Corporation.

Pearce, P. and Caltabiano, M. (1983) Inferring travel motivation from travellers' experiences. Journal of Travel Research, 22: 16-20.

Young, M. (1999) The relationship between tourist motivations and the interpretation of place meanings. Tourism Geographies, 1(4): 387-405.

Yunis, E. (2006) Religious Tourism and Sustainability, paper delivered at International Conference on Religious Tourism. Accessed on 6/11/07 http://icoret.metacanvas.com/EN/conference/programme papers.html.

Sacred Britain (2006) Sacred Britain Strategy Document, accessed on 7/12/17 
http://cofe.anglican.org/about/builtheritage/buildingfaith/sacredbritainstrategy.pdf.

Sacred Sussex (2007) Information on Sacred Sussex, accessed on 16/11/07 http://www.sacredsussex.org/News.htm.

Shackley, M. (2001) Managing Sacred Sites. Thomson, London.

Shackley, M. (2002) Space, Sanctity and Service: the English Cathedral as Heterotopia. International Journal of Tourism Research, 4: 345-352.

Sharpley, R. and Sundaram, P. (2005) Tourism: a sacred journey? The case of ashram tourism, India. International Journal of Tourism Research, 7: 161-171.

Uzzell, D. (1989) Heritage Interpretation Volume 2: The Visitor Experience. Belhaven Press, London.

Voase, R. (2007) 'Visiting a Cathedral: The Consumer Psychology of a 'Rich Experience', International Journal of Heritage Studies, 13(1): 41 - 55. 
Appendix 1: Questionnaire survey used in this research

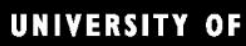 \\ Chichester}

\section{Chichester Cathedral Visitor Survey 2007}

Time of Visit:

Date of Visit:

1. Please state your gender:

- 1. Male

- 2. Female

2. Please state your age:

- 1. $15-29$

- 4. $50-59$

- 2. $30-39$

- 5. $60-69$

- 3. $40-49$

- $6.70+$

3. Please indicate the first section of your postal code:

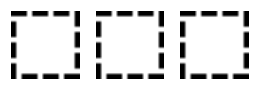
I

4. How many people are in your Group?<smiles>[CH]1[CH]C[CH]1</smiles>

If you are a member of a group, which of the following describes your group:

- 2. Family

- 4. Friends

- 3. Organised Group

5. Are you currently?

- 1. Employed

- 2. Retired/Senior Citizen

- 3. Unemployed

- 4. Student

6. If employed, what is your job description/title? (Please specify) 
7. How many times have you visited Chichester Cathedral?
- 1. $1^{\text {st }}$ visit
- 3. $3^{\text {rd }}$ visit
- 2. $2^{\text {nd }}$ visit
- 4. 4 or more times

8. Had you planned to visit the Cathedral today?
- 1. Yes
- 2. No

9. How did you first find out about the Cathedral?

- 1. Internet, please name site:

- 2. Tourist Information Office, please state location:
- 3. Friend/relative

- 4. Newspaper/magazine, please give title of publication:
- 5. Saw it whilst in Chichester

- 6. Other source (please state):

10. Was all the information you needed to plan your visit readily available? - 1. Yes

- 2. No, please state what was missing?

11. In your own words, please state what aspect(s) of your visit today has been particularly satisfying:

12. Has any aspect of your visit today been disappointing in any way? Please give details:

13. What is your MAIN reason for visiting the Cathedral today? (Please tick one box)

- 1.The architecture

- 2. History of the building

- 3. Pilgrimage or worship

- 4. Prayer or reflection

- 5. Peace and solitude

- 6. Curiosity
- 7. Visiting with a group

- 8. Because it is a free tourist attraction

- 9. Other, please state:

14. Please rank the importance of the following aspects of your visit: Very Important
A. Architecture/Beauty of the building
B. Historical interest of the building

12

2
34

$\begin{array}{lllll}1 & 2 & 3 & 4 & 5\end{array}$

Least 
C. Quiet areas for prayer or reflection

D. Peace and Solitude

E. Free Entry

F. Information about the Cathedral

G. Guided Tours

H. Exhibitions inside the Cathedral

I. Ease of Access

J. Cathedral Café

K. Cathedral Shop

15. How satisfied are you with the following aspects of your visit:

\section{Very satisfied}

Least

$\begin{array}{llllll}\text { A. Helpfulness of Cathedral Staff } & 1 & 2 & 3 & 4 & 5 \\ \text { B. General atmosphere \& ambience } & 1 & 2 & 3 & 4 & 5 \\ \text { C. Quiet areas for prayer or reflection } & 1 & 2 & 3 & 4 & 5 \\ \text { D. Information about the Cathedral } & 1 & 2 & 3 & 4 & 5 \\ \text { E. Ease of Access } & 1 & 2 & 3 & 4 & 5 \\ \text { F. Cathedral Cafe } & 1 & 2 & 3 & 4 & 5 \\ \text { G. Cathedral Shop } & 1 & 2 & 3 & 4 & 5 \\ \text { H. Guided Tours } & 1 & 2 & 3 & 4 & 5\end{array}$

not used

16. Have you visited, or do you intend to visit, the shop today?
- 1. Yes
- 2. No

17. If you are not visiting the shop today please give a reason:

- 1. Insufficient time

- 3. Other, please state:

- 2. Not interested in shopping

18. Have you visited, or do you intend to visit, the café today? - 1. Yes - 2. No

19. If you are not visiting the cafe today, please give a reason:

- 1. Insufficient time

- 3. Other, please state:

- 2. Visiting a café in town

20. During your visit today did you notice any appeals for donations towards the upkeep and running of the Cathedral?
- 1. Yes, one
- 2.Yes, several
3. No

21. Did you notice that the donation points were collecting for different funds?
- 1. Yes
2. No

22. Did you choose to make a donation today? 

- 1.Yes, cash
3. No

23. If you made a donation today, how much did you donate?

- 1. $<£ 1$

- 3. £3-£4

- 5. $£ 7-£ 8$

- 2. £1-£2

4. £5-£6

6. $£ 9+$

24. It costs approximately $£ 3,000$ a day to keep the Cathedral open for visitors and worship. Donations from visitors are a vital source of income. What do you think is an appropriate minimum donation to suggest to visitors?

Please state amount:

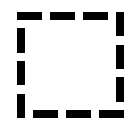

25. Would you have visited today if an entry fee of $£ 4$ had been charged?
- 1. Yes
- 2. No

26. Do you expect to visit the Cathedral again?
- 1. Yes
- 2. No

27. Would you recommend the Cathedral to others?
- 1. Yes
- 2. No

28. What three words would you use to describe the Cathedral: 


\section{Appendix 2: Most Satisfying Aspects of Visit}

\section{Aspects directly relating to Architecture/Building (167)}

$\begin{array}{ll}\text { Architecture } & 56 \\ \text { Windows } & 34 \\ \text { Artwork/craftsmanship } & 22 \\ \text { Tombs/stonework/statues } & 15 \\ \text { Maintenance/Preservation } & 9 \\ \text { Tapestries } & 7 \\ \text { Mixture of artistic styles } & 6 \\ \text { Altars } & 3 \\ \text { Chapels } & 3 \\ \text { Location } & 3 \\ \text { Memorials } & 3 \\ \text { Mosaics } & 2 \\ \text { Cloisters } & 2 \\ \text { Treasury } & 2\end{array}$

Aspects relating to Spiritual/Emotional Experience (125)

Peace/quiet/solitude $\quad 51$

Atmosphere/ambience 23

Staff/welcome at door $\quad 24$

Opportunity to pray/reflect/

pay respects/light candles

Christian witness of Cathedral 8

Prayers read on each hour 3

Aspects relating to Visitor Experience (80)

$\begin{array}{ll}\text { Information leaflets } & 27 \text { (children's 2, foreign language leaflets 2) } \\ \text { Guides/tour } & 17 \\ \text { Freedom to roam } & 11 \\ \text { Free entry } & 9 \\ \text { Music/organ/choir rehearsal } & \\ \text { Shop/café } & 3 \\ \text { Wheelchair Access } & 3 \\ \text { Ability to take flash photos } & 1 \\ \text { Cheap car park } & 1\end{array}$

Aspects relating to History of Cathedral

\section{Miscellaneous (4)}

Opportunity to compare with Winchester Cathedral Sharing experience with family/friends 


\section{Appendix 3: Least Satisfying Aspects of Visit}

Aspects directly relating to Visitor Experience (15)

No access directly from Bishop's Palace Gardens

Bell Tower Shop closed

No access upstairs

No access to Lady Chapel

Concern that prayer candle holders are unsafe

Bit too noisy

No music

Would have like to have seen organ

Shortage of toilets

Would have liked to have heard bells ringing

Lack of signs to cathedral shop

Unnecessary invitations to pray

Aspects directly relating to Information about History (8)

No translations of Latin Inscriptions

No record of mason's who built cathedral

Information leaflet disappointing

Some things not labelled

The bits the guides missed

Lack of info in leaflets about the windows

No one knew how the font was emptied

Aspects directly relating to Architecture/Building (6)

Too modern/60s 'improvements'

'Windows'

Altar Curtain

Modern Altar pieces

Mosaics, ceiling \& paintings

Miscellaneous (2)

George Chapel dedicated to military

Bad Weather 


\section{Appendix 4: Adjectives Used to Describe The Cathedral}

\begin{tabular}{|c|c|}
\hline $\begin{array}{l}\text { PEACE: } \\
\text { Peace(ful)/Tranquil/Calm/Calming/Quiet/Silent/Serene(ity) }\end{array}$ & 188 \\
\hline $\begin{array}{l}\text { BEAUTY/ARCHITECTURE: } \\
\text { Amazing/ Attractive/ Art(istic)Beautiful/Breath-taking/Bright/Colourful } \\
\text { /Enjoyable/Elegant/Excellent/Extraordinary/First-Class/Inspired/ } \\
\text { Gorgeous/Lovely/Memorable/Nice/Outstanding/Pleasant/Pleasurable/ } \\
\text { Pretty/Decorative/Fantastic/Ornate/Stunning/Superb/Splendid/Wonderful/ } \\
\text { Satisfying/Timeless/Unmissable/Worthwhile/Unique/ Eclectic/Mixed styles/ } \\
\text { Old \& New Mixed/Varied/Norman/English/Romanesque/Architecture/ } \\
\text { Stained-Glass/Traditional/Stone }\end{array}$ & 184 \\
\hline $\begin{array}{l}\text { SIZE: } \\
\text { Big/Grand/Bold/Great/Compact/Contained/Important/Impressive/ } \\
\text { Imposing/Magnificent/Majestic/Large/Landmark/Monument(al)/ } \\
\text { Towering/Vast/Striking/Tall/Solid/Spacious }\end{array}$ & 98 \\
\hline $\begin{array}{l}\text { EDUCATIONAL: } \\
\text { Cultural/Educational/Edifying/Fascinating/Intriguing/Surprising/ } \\
\text { Informative/Interesting }\end{array}$ & 87 \\
\hline $\begin{array}{l}\text { HISTORY: } \\
\text { Ancient/Continuity/Historic/Old/Heritage/Tradition }\end{array}$ & 77 \\
\hline $\begin{array}{l}\text { SPIRITUAL/EMOTIONAL EXPERIENCE: } \\
\text { Presence of God/ Spiritual/Respectful/Reverent/Sincere/ Pure/ } \\
\text { Solemn/ Awe-inspiring/Thought-provoking/Moving/Inspirational/ } \\
\text { Exhilarating/Poignant/Reflective/Fulfilling/Humbling/Restful/Ethereal/ } \\
\text { Spiritually Uplifting/Soothing/Uplifting/Stress-free/Transcendent/Relaxing }\end{array}$ & 72 \\
\hline $\begin{array}{l}\text { WELCOMING ATMOSPHERE: } \\
\text { Ambience/Atmospheric/Comfortable/Comforting/Cool/Friendly/Homely/ } \\
\text { Hospitable/Welcoming/Lovely atmosphere/Inviting/Intimate/Warm/Vibrant }\end{array}$ & 61 \\
\hline $\begin{array}{l}\text { SIMPLICITY: } \\
\text { Airy/Clear/Light/Simple/Not ornate/Unadorned/Uncluttered }\end{array}$ & 34 \\
\hline $\begin{array}{l}\text { RELIGIOUS FUNCTION: } \\
\text { Alive/Anglican/ Christian/God's House/Holy/Interaction life \& } \\
\text { worship/Living/Used/Religious/Prayerful/Worship }\end{array}$ & 29 \\
\hline $\begin{array}{l}\text { MAINTENANCE: } \\
\text { Cared-for/ Clean \& restored/ Well-kept/Well-loved/Well-maintained/ } \\
\text { Well-organised/Well-presented/Well-preserved/Well-restored }\end{array}$ & 28 \\
\hline $\begin{array}{l}\text { NEGATIVE: } \\
\text { Boring/False/Political/Sad/Noisy/Ordinary/Disappointing/ Inappropriate, } \\
\text { ugly furniture/Too modern/Lacking medieval carvings /Not much historic } \\
\text { appeal/Ordinary }\end{array}$ & 15 \\
\hline $\begin{array}{l}\text { ACCESS: } \\
\text { Accessible/Free }\end{array}$ & 4 \\
\hline
\end{tabular}

